\title{
Gaziantep ve Antakya Kentsel Sit Alanlarının Geleneksel Doku ve Mekânsal Gelişim Açısından Karşılaştırılması
}

\author{
Saliha TAŞÇIOĞLU ${ }^{1, *}$ \\ ${ }^{1}$ Kilis 7 Aralık Üniversitesi, Teknik Bilimler MYO, Park ve Bahçe Bitkileri Bölümü, 79000, KİLİS
}

\section{Öz}

Çalışma Antakya ve Gaziantep kentlerinin kurulumundan itibaren, tarihsel süreçteki değişim ve gelişimini belirlemek, geleneksel doku analizleri ile aralarındaki farklılık ve benzerliklerin ortaya konulmasını amaçlamıştır. Konuya katkı sağlayacak çalışmaların incelenmesi sonucu her iki kent için geleneksel doku analiz çizelgesi oluşturulmuştur. Antakya ve Gaziantep kentinin tarihsel gelişimi ile mekânsal gelişimi 3 döneme ayrılarak incelenmiştir. İncelemeler sonucunda anıtsal ve sivil mimarlık örnekleri, ulaşım ağı ve yeşil alan analiz haritaları oluşturulmuştur. Çalışmada her iki kentin de mekânsal gelişimin alınan kararlar doğrultusunda şekillendiği ve yıllar içerisinde dokuda bazı kayıpların olduğu belirlenmiştir. Yakın konumda bulunan iki kentin yapısal ve mimari olarak farklılıklar içerebildiği belirlenmiş, bu bağlamda tarihi kentlerin kendine has bir koruma uygulamasına tabi tutulmasının önemine vurgu yapılmıştır.

Anahtar Kelimeler: Tarihi kentler, mekansal gelişim, geleneksel doku, antakya, gaziantep.

\section{Comparison of Gaziantep and Antakya Urban Protected Areas in terms of Traditional Texture and Spatial Development}

\begin{abstract}
The aim of this study is to determine the change and development in the historical process since the establishment of the cities of Antakya and Gaziantep, and to reveal the differences and similarities between them and traditional tissue analyzes. As a result of the studies that will contribute to the subject, a traditional tissue analysis table has been prepared for both cities. The historical development and the spatial development of Antakya and Gaziantep were divided into three periods. As a result of the investigations, monumental and civil architecture examples, Transportation Network and Green Area analysis maps were created. In the study, it was determined that the spatial development of both cities was shaped according to the decisions taken and there were some losses in the tissue over the years. It was determined that the two cities located nearby could have structural and architectural differences and in this context, it was emphasized the importance of subjecting historical cities to a unique protection practice.
\end{abstract}

Keywords: Historical cities, spatial development, traditional texture, antakya, Gaziantep. 


\section{Giriş}

Kent zaman içerisinde insan gereksinimine bağlı olarak mekânsal boyutta, bazen de sosyal ve ekonomik süreçlerin etkisiyle biçimlenmektedir (Arslan, 1993). Bu nedenle kentleri sadece fiziksel varlık olarak mekân anlamında değerlendirmek yanlış bir yaklaşımdır. Çünkü kentler de her varlık gibi bir ruha, kimliğe sahiptirler (Esendemir, 2015). Bu anlamda değerlendirildiğinde zaman içerisinde biçimlenen ve günümüze kadar ulaşmayı başarmış tarihi kent dokularının, yörenin kentsel karakterine, ekolojik koşulları ve sosyo-ekonomik yapısına göre, planlama çalışmalarına tabi tutulması konusu büyük önem taşımaktadır. $\mathrm{Bu}$ doğrultuda gerçekleştirilecek olan çalışmalarının eski doku ile uyum içinde olması, sürdürülebilirlik anlamında olumlu bir katkı sağlamaktadır. Özellikle son 30 yılda kentsel sitlerde son derece sağlıksız yeni bir mimari ortam oluşmuş, kültür varlığı yapılar kendi hallerine terk edilerek yıkılma noktasına gelmişler, yıkılanların yerine ise niteliksiz yapılar inşa edilmiştir (Eyüpgiller, 2013). Bu sebepler mevcut şehir yapısında önemli ve yeni yükler oluşmasına sebep olmaktadır. Çünkü geleneksel şehirlere kentsel genişleme ile darbe vurularak, hizmet yarıçapı genişletilmiştir. İnsanları şehre geri çekecek gerçek çözümler gerektirmekte ve bu önlemler sadece yapıları korumaktan daha fazlasını yapmak gerektiği anlamina gelmektedir (Cohen,1999).

Bu çalışmada öncelikle Gaziantep ve Antakya Kentsel Sit Alanının dokusu irdelenerek, geçmişten günümüze kadar meydana gelmiş olan değişimler saptanmaya çalışılmıştır. Bu iki il yakın mesafede bulunması ve benzer mimari özelliklere sahip olduğunun düşünülmesi nedeniyle tercih edilmiştir. Antakya Kentsel Sit Alanı 1929-1980 ve 2009, Gaziantep Kentsel Sit Alanı ise 1935-1969 ve 2010 olarak 3 dönemde incelenmiştir. Anıtsal ve sivil yapı, ulaşım ağı ve yeşil alan olarak haritalar oluşturulmuştur. Bulgular sonucunda bu kadar yakın mesafede bulunan iki kent içerisinde bile farklılıklar olduğu değerlendirildiğinde, ülke genelinde yapılan koruma çalışmalarının belli bir kalıp ve standart üzerinden yapılmasının doğru olmayacağını söylemek yanlış olmayacaktır. Bu bağlamda tarihi yapılar ve çevrelerinin geçmişin bilgi kaynağı olarak düşünülerek, sürdürülebilirlik kavramı içerisinde korunması, her bir kimlik öğesinin onu günümüze taşıyan bir değer olduğu göz ardı edilmemelidir.

\section{Materyal ve Metot}

\subsection{Materyal}

Çalışmada materyal olarak;

- Antakya ve Gaziantep Nazım İmar Planları,

- 1/1000 ölçekli Antakya ve Gaziantep Halihazır Planı,

- 1/1000 ölçekli Antakya ve Gaziantep Koruma Amaçlı İmar Planı,

- Adana ve Gaziantep Kültür Varlıklarını Koruma Bölge Kurulu'ndan ve Kültür ve Turizm Müdürlüğü'nden alınan İl Kültür ve Turizm Envanterleri ve dokümanlar,

- Kentsel sit alanlarının tarihi ve mekânsal gelişim sürecini gösteren kroki, plan, harita, fotoğraflar, yerel halktan geçmişe yönelik bilgiler,

- Araştırma alanında çekilen eski ve güncel fotoğraflar, görsel inceleme ve izlenimler, konu ile ilgili daha önce yapılmış olan çalışmalar,

- Autocad 2014 ve Photoshop CS2 programları kullanılmıştır.

\subsection{Metot}

Çalışmanın metodu üç aşamadan oluşmaktadır:

1- Çalışma alanlarının sınırlarının belirlenmesi,

2- Geleneksel doku analizleri ve tarihsel gelişim

3- Çalışma alanlarının mekansal gelişim haritalarının hazırlanması

\section{Alanın Sınırlarının Belirlenmesi}

Çalışma alanı olarak 1/1000 ölçekli Antakya Koruma Amaçlı İmar Planında yer alan Kentsel Sit Alanı ve 1/1000 ölçekli Gaziantep Koruma Amaçlı İmar Planında yer alan Antakya Kentsel Sit Alanı olarak seçilmiştir. Kentsel Sit Alanlarının konumları Şekil 1'de verilmiştir.

Antakya Kentsel Sit Alanı: 1975 yılında ilan edilen Antakya Kentsel Sit Alanı 70 hektardır. Alan, farklı medeniyetlere ve topluluklara ait pek çok tarihi ve kültürel varlığı içermektedir.

Gaziantep Kentsel Sit Alanı: 1979 yılında ilan edilen Gaziantep Kentsel Sit Alanı 83,86 hektardır. Alan 
çok sayıda ticari özellikleri içeren yapı içermekte ve yenileme çalışmaları yapılan örnekler içermektedir. \% 4'ü Şehitkamil, \% 96'sı Şahinbey Belediyesinde olmak üzere iki ayrı belediye sınırında yer almaktadır.

Çalışma sırasında literatür incelemeleri ve alan seçimine ilişkin ölçütler değerlendirilmiştir. Ancak ilk aşamada alan seçiminde aşağıda sıralanan ölçütler dikkate alınmıştır.

1-Yerleşim karakteri bakımından bölgeyi ağırlıklı olarak temsil edebilmesi,

2-Konumları nedeniyle günlük kullanımının yoğun olması,

3-Tarihi ve kültürel zenginlik anlamında çeşitlilik içermesi

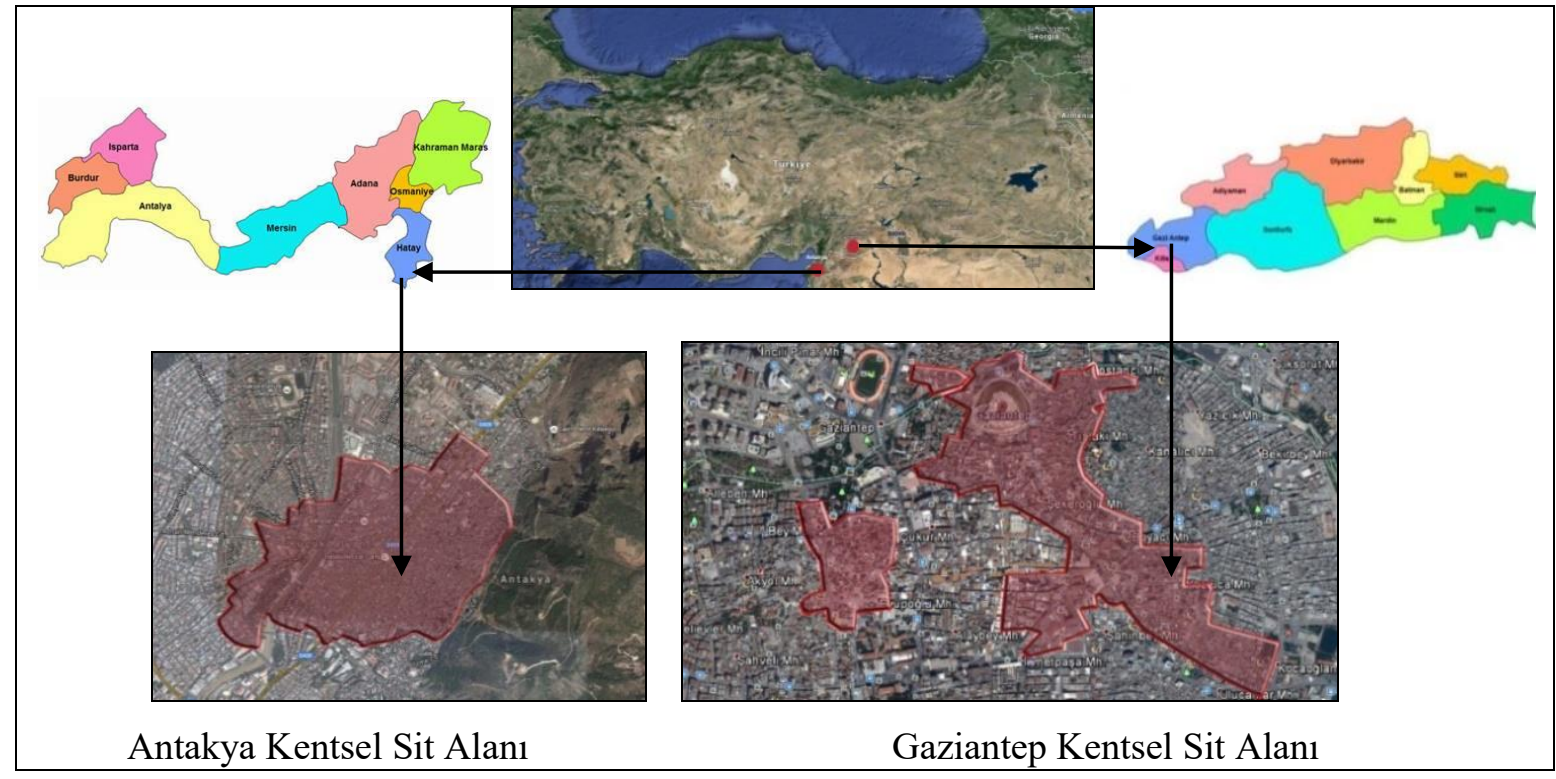

Şekil 1. Çalışma Alanı Olarak Seçilen Kentsel Sit Alanlarının Konumları

\section{Geleneksel Doku Analizleri ve Tarihsel Gelişim}

Antakya ve Gaziantep kentlerinin tarihsel gelişimi ve değişimleri dönemler halinde incelenmiştir. Kentlerin şekillenmede önemli etkisi olan Avlu, Yapı, Sokak, Meydan öğeleri 22 ölçüt üzerinden yapılan analizler doğrultusunda geleneksel doku çizelgesi oluşturulmuştur. Geleneksel doku çizelgelerinin oluşturulmasında;

Antakya için Asarcıklı (1989), Erdoğan (1996), Demir (1996), Tekin (2000), Arıman (2002), Rifaioğlu (2003), Akbay (2006), Ömeroğlu (2006), Güzer (2007), Özalp (2008), Yoldaş (2014),

Gaziantep için Erdoğan (1996), Başgelen (1999), Ünal (2001), Çetin (2001), Başel (2004), Tatlıgil (2005),Dik (2006), Yüce (2010), Kıratlı (2013)’nın çalışmalarından yararlanılmıştır.

\section{Çalışma Alanının Mekânsal Değiş̧im Haritalarının Oluşturulması}

Yöntemin ilk aşamasında seçilen çalışma alanlarıyla ilgili plan, proje, resim, uydu görüntüsü, restorasyon çalışmasına ait veriler, Koruma Amaçlı İmar Planı, Koruma çalışmaları, Taşınmaz Kültür Varlıklarının belirli dönemlere ait durumunu gösteren harita ve fotoğraflar, yerinde inceleme ve analiz, resmi kurumlardan alınan raporlar, yurt dışı ve yurt içi yayın ve bilimsel yayınlar incelenmiş ve değişim haritaları oluşturulmuştur. Gaziantep Kenti için 1935-2010, Antakya için ise 1929-2009 yılları arasındaki değişimin ve kayıpların belirlenebilmesi amacıyla: anıtsal, ve sivil yapılar, ulaşım ağı, yeşil alanları gösteren haritalar Bilgisayar Destekli Tasarım yazılımları kullanılarak oluşturulmuştur.

\section{Bulgular ve Tartışma}

\section{Gaziantep Kenti Tarihsel ve Kentsel Gelişimi ve Geleneksel Doku Analizi}

Anadolu'nun ilk yerleşim yerlerinden biri olan Gaziantep'in tarih öncesi çağlardan günümüze kadar olan tarihi süreçteki yapısal değişimi Tablo 1'de verilmiştir. 
Tablo 1. Gaziantep Tarihi ve Tarihsel Süreçte Kentsel Yapı Değişimi

\begin{tabular}{|c|c|}
\hline $\begin{array}{l}\text { Tarihi } \\
\text { dönem }\end{array}$ & Yerleşim Şekli \\
\hline $\begin{array}{l}\text { Geç Kalkolitik } \\
\text { M.Ö.3750 }\end{array}$ & İlk yerleşim kent merkezindeki höyüğün güney kısmına kurulmuştur \\
\hline Geç Hitit & M.Ö.1200-612 \\
\hline Pers & M.Ö.612-333 \\
\hline Selevkos & M.Ö.333-30 M, S.64 \\
\hline $\begin{array}{l}\text { Roma M.Ö.64 } \\
\text { M.S.395 }\end{array}$ & $\begin{array}{l}\text { Antep Kalesinin Kuzey kesiminde Küçük bir kale inşa edilmiş ve birkaç kule yapılmış. Bölgede } \\
\text { "Teba" adında bir yerleşim yeri bulunmaktadır. }\end{array}$ \\
\hline Bizans & M.S.395-698 \\
\hline $\begin{array}{l}\text { Emevi } \\
\text { ve Abbasi }\end{array}$ & M.S. $638-1077$ \\
\hline $\begin{array}{l}\text { Anadolu Selçuklu } \\
\text { M.S. 1077-1516 }\end{array}$ & $\begin{array}{l}\text { 14.yy başlarında kuzeyde Alleben deresine, batıda Ömeriye Cami'nin batısında Maarif semtine, } \\
\text { güneybatıda Eyüpoğlu Cami'sine ulaşmıştır. }\end{array}$ \\
\hline
\end{tabular}

Kent Kalenin hemen güneyi ile Türktepe güney yamacında Boyacı camiine kadar uzanan dar bir kuşak, kale arkasında Ali Nacar Mahallesi'nin ve onlardan bağımsız Eyüboğlu, Eblehan, Akyol ve Bey'i içine alan ve Beytepe yamacında oluşan bir ikinci grup ile kale dışında yayılım göstermeye başlamıştır. Kentin kalenin kuzeyinde Tabakhane, Ali Neccar Camisi çevresine, batıda ise Seferoğlu Mahallesi'ne kadar uzanmış olduğu tahmin edilmektedir (Kuban, 2001)(Şekil 2).

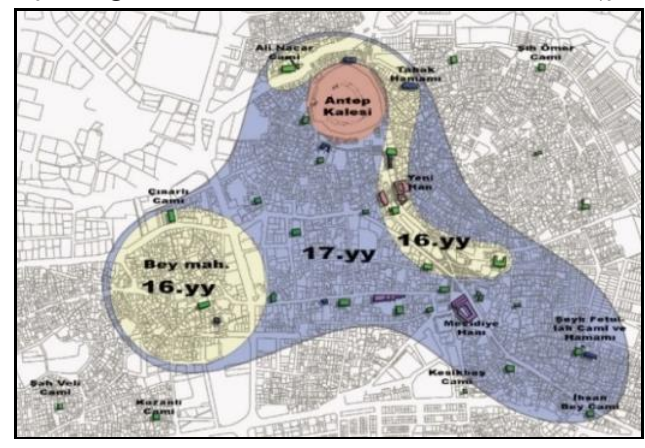

Şekil 2. Gaziantep Osmanlı Dönemi Yapıları ve Gelişim (Evliya Çelebi, Uğur, 2004, Kuban,2001'den geliştirilerek)

Osmanlı Dönemi M.S. 1516-1923
Antep'te 1871 yılında 9742 hane bulunmaktadır. Bunların 47.599'u Müslüman, 9833'ü Hıristiyan, 544'ü Musevi olmak üzere 57.976 kişi yaşamaktadır. 1889 'da nüfus 81.040 kişiye, 1899 'da ise 85.053 olarak belirtilmiştir (Özdeğer,1996) (Tablo 2).

Tablo 2.Gaziantep'in 20. yy Başına Kadar Nüfus Değişimi (Güzelbey,1966, Başgelen,1999, Çam,2006)

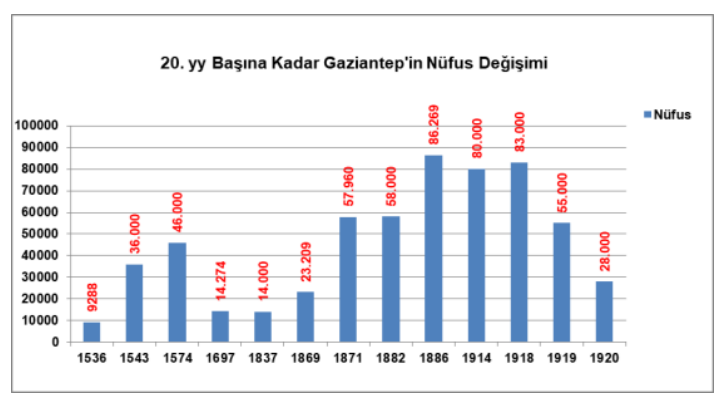

19. Yüzyıl sonunda Gaziantep'in 84 mahallesi ve 80.000 civarında nüfusu olduğu bilindiğine göre o sırada 20-30.000 arasında bir nüfusa sahip olduğu düşünülmektedir (Kuban,2001).

1919 yılında başlayan ve iki yıl süren Fransız işgali kente çok fazla zarar vermiştir.1921 sonrası hızlı gelişme gösteren kentte yeni mahalleler oluşmuştur. Kale merkezli bir kurulum gösteren kent eski kent dokusunu saracak şekilde gelişmiştir (Ünal, 2001). Cumhuriyetin ilk yıllarında merkez olarak kaleyi aldığımızda konut alanları, yarıçapı 500- 600 metreyi geçmeyen bir alan içerisinde yer almaktayd1 (Tuncel, 1996). 
Gaziantep geleneksel dokusunun belirlenebilmesi için, daha önceden yapılan çalışmalardan yararlanılmıştır. Toplam 22 ölçüt üzerinden Avlu, Yapı, Sokak, Meydan ile ilgili analizler yapılmıştır (Tablo 3).

Tablo 3. Gaziantep Geleneksel Doku Analiz Tablosu

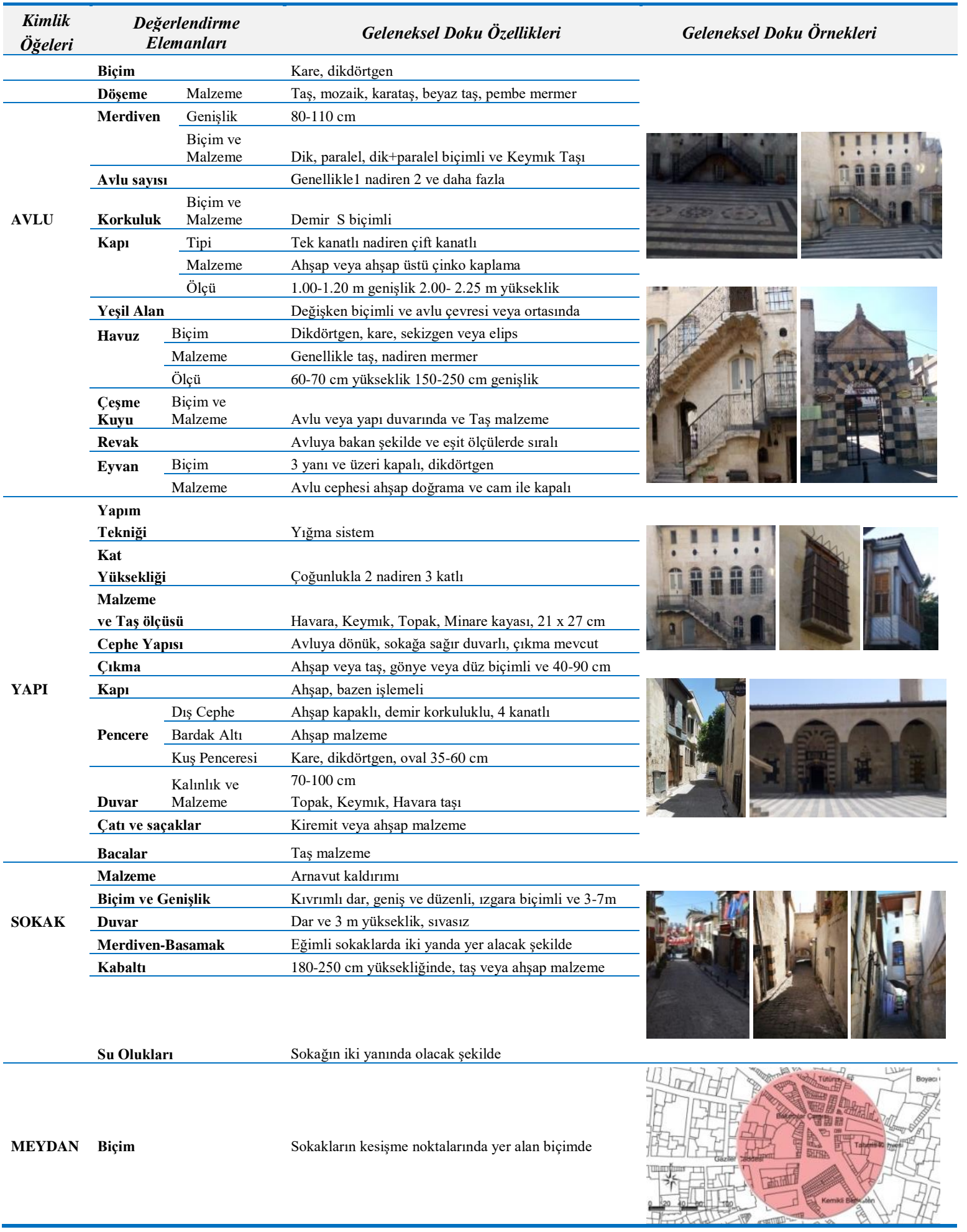

Yapılan geleneksel doku analiz çalışmasında yapılarda farklı taş kullanımının ağırlıkta olduğu, sokakların ise kıvrımlı ve yer yer daralan bir formda olduğu belirlenmiştir. 


\section{Antakya Kenti Tarihsel ve Kentsel Gelişimi ve Geleneksel Doku Analizi}

Antakya'nın tarih öncesi çağlardan günümüze kadar olan tarihi süreçteki yapısal değişimi Tablo 4'de verilmiştir.

Tablo 4. Antakya Tarihi ve Tarihsel Süreçte Kentsel Yapı Değişimi

$\begin{array}{cc}\text { Tarihi } & \text { Yerleşim Şekli } \\ \text { Dönem } & \text { X̧em }\end{array}$

Kent, mimar Xenarius tarafindan Hippodamos Şemasının ilkelerine göre birbirlerine 112 x $56 \mathrm{~m}$ dik açılarla kesen sokakların oluşturduğu yapı adaları üzerine oturmaktadır (Rifaioğlu, 2015) (Şekil $3)$.
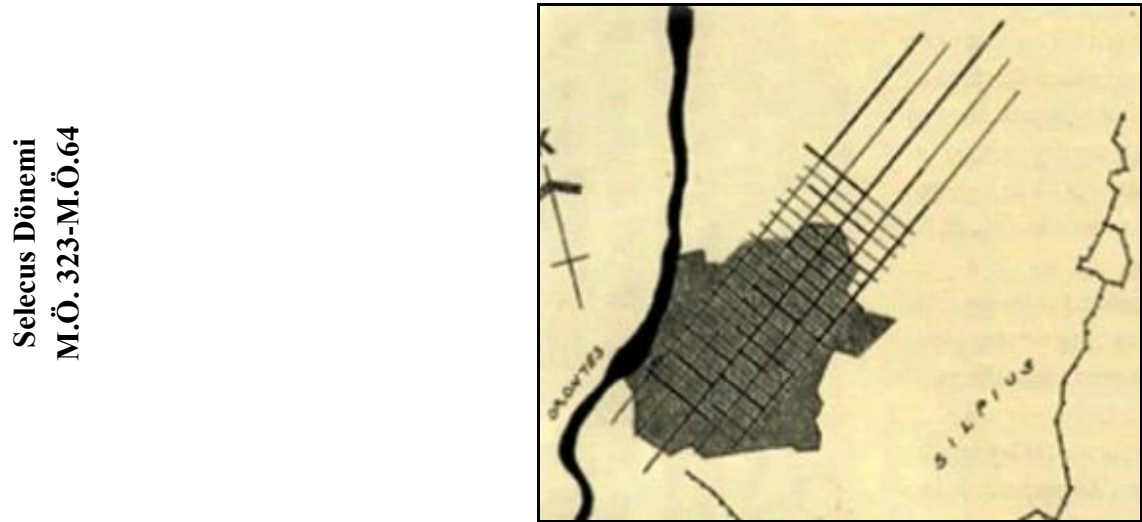

Şekil 3. Antakya Kentinin Kuruluşundaki Hippodamos Planı (Demir, 1996)

Roma döneminde 1zgara plan geliştirilmiş ve kenti kuzey-güney istikametinde 2.956 metre (2. Roma Mili) uzunluğunda sütunlu yol inşa edilmiştir (Rifaioğlu, 2015). Tüm bu imar faaliyetlerinden sonra M.S. 115 yılında meydana gelen şiddetli deprem Antakya ve Defne'de büyük tahribat yapmış, çok sayıda insan hayatını kaybetmiştir (Gündüz,2009).

: $\infty$ Antakya'nın 1zgara sokak sistemi bu dönemden itibaren değişmeye başlamıştır.
đֶ. gömüldüğünü bildirmektedir. 250.000 kişinin hayatını kaybettiği depremde dağın eteğindeki evlerin kurtulduğunu, ancak geriye kalanların tamamen yok olduğunu belirtmektedir. Depremden sonra meydana gelen yangının ise Büyük Kiliseyi ve kalan evleri tahrip ettiğini ifade etmektedir (Sbeinati et. al, 2005).

:

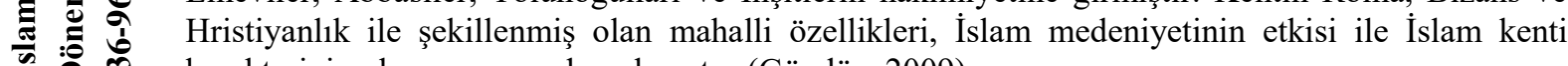
$. \bar{\Xi}:$ :

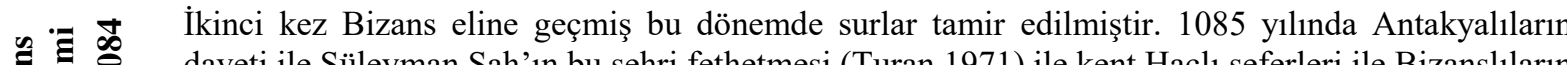
daveti ile Süleyman Şah'ın bu şehri fethetmesi (Turan,1971) ile kent Haçlı seferleri ile Bizanslıların

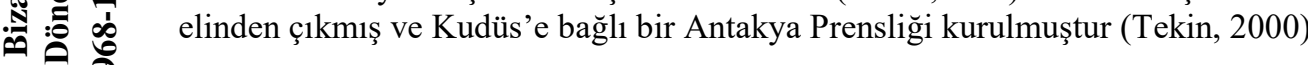

Haçlı orduları Antakya'yı 1098 yılında ele geçirmişlerdir. 170 yıl haçlıların egemenliğinde kalmıştır. Hristiyanlığın merkezi haline gelen kent Kudüs krallığına bağlı dukalık olarak yönetilmiştir (Kocaoğlu, 2016).

Kent Memluk Sultanı Baybars tarafından ele geçirilmiştir. İbn Batuta (1325) en sağlam surlara sahip olan kentin surlarının Sultan Baybars'ın fethi sırasında tahrip olduğunu belirtmiştir (Gökhan,2010). Bir kilisenin üzerine bugün Habib-i Neccar camisini inşa ettirmiştir. 
Tablo 4. (Devam)

\begin{tabular}{cc}
\hline $\begin{array}{c}\text { Tarihi } \\
\text { Dönem }\end{array}$ & \multicolumn{1}{c}{ Yerleşim Şekli } \\
\hline & 17 yy 'da 8 sarayı, sağlam surları olan, üç adedinin üzeri kapalı 7 adet çarşısı bulunan kentte Osmanlı \\
döneminde de depremler olmuştur. 1615 yllında yaşanan depremde kent büyük zarar görmüştür. \\
Bizans döneminde değişmeye başlayan 1zgara sistemli doku organik sokak dokusuna dönüşüş̧ür. \\
1772 yılında Abraham Parsons tarafindan çizilen gravür ve yazılarından doğu kapısı tarafinda \\
yapılaşmanın olduğunu belirtilmiştir (Demir, 1996) (Şekil 4).
\end{tabular}

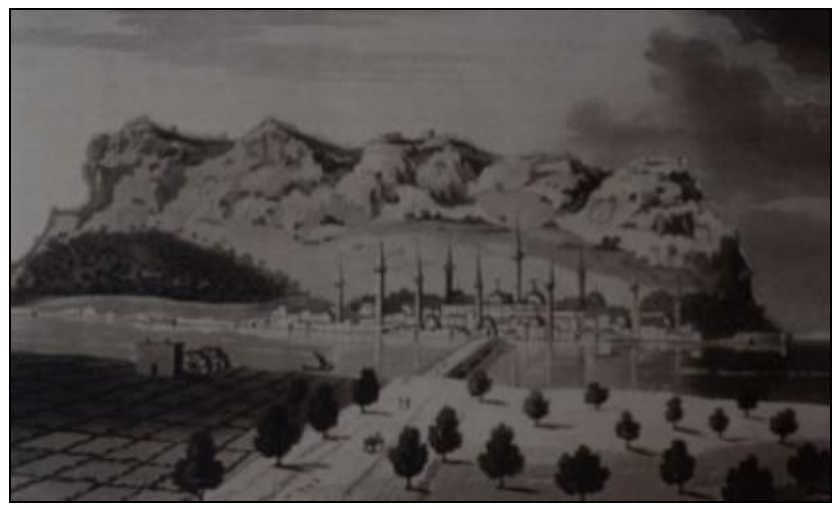

Şekil 4. Abraham Parsons'un Seyahatnamesinde Antakya (Demir, 1996).

1822 ve 1872 yıllarında yaşanılan depremler kente büyük zarar vermiştir.1891 y1lında 1 Kışla, 24 cami, 28 Mescit, 2 Tekke, 42 okul, 3 kilise, 5 hamam, 117 çeşme, 3374 hane, 1451 dükkân, 35 toptancı mağazası, 20 han, 3 otel, 14 kahvehane, 1 eczane, 25 firın, 5 su değirmeni, 9 sabunhane, 13 ipek atölyesi ile kaymakamın resmi ikametgahı olan bir konak bulunmaktadır. (Demir, 1996). Antakya'nın farklı yıllara ait nüfus değişimi Tablo 5'de gösterilmiştir.

Tablo 5. Antakya'nın 20. yy Başına Kadar Nüfus Değişimi (Sahillioğlu,1991,Tekin,2000,Gündüz ve Gülcü, 2009, Tozlu,2009)
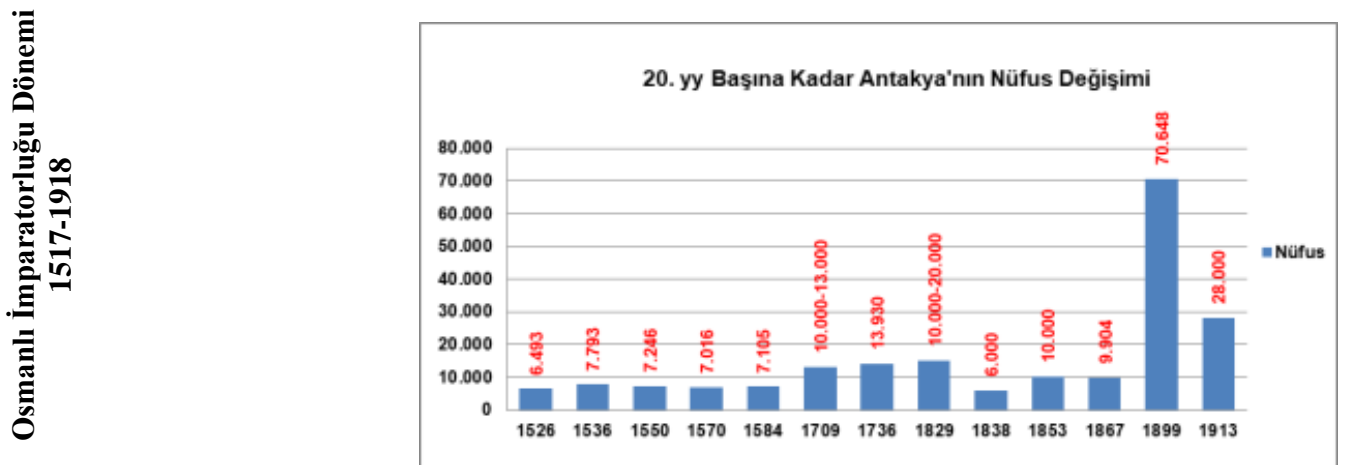

1935 yılına gelindiğinde ise Weulersse'nin yaptığı çalışmada, Antakya nüfusunun temelini oluşturan Türklerin 18.000 nüfus ile 27 mahallede ikamet ettiği ifade edilmektedir.

Antakya için, Avlu, Yapı, Sokak, Meydan başlıkları altında Toplam 22 ölçüt üzerinden analizler yapılmıștır. Bu analizler Tablo 6'da detaylı olarak yer almaktadır. 
Tablo 6. Antakya Geleneksel Doku Analiz Tablosu

\begin{tabular}{|c|c|c|c|c|}
\hline $\begin{array}{l}\text { Kimlik } \\
\text { Ö̆ğeleri }\end{array}$ & $\begin{array}{l}\text { Değerle } \\
\text { Eleman }\end{array}$ & $\begin{array}{l}\text { lirme } \\
\mathrm{rl}\end{array}$ & Geleneksel Doku Özellikleri & Geleneksel Doku Örnekleri \\
\hline & Biçim & & Kare, dikdörtgen & \\
\hline & Döşeme & Malzeme & $\begin{array}{l}\text { Kesme taş, nadiren karo veya dökme mozaik, } \\
\text { mermer }\end{array}$ & \\
\hline & Merdive & Genişlik & $80-110 \mathrm{~cm}$ & \\
\hline & & $\begin{array}{l}\text { Biçim ve } \\
\text { Malzeme }\end{array}$ & Dik, paralel, duvara birleşik ve taş & \\
\hline & Avlu say & & Genellikle 1 nadiren 2 ve daha fazla & \\
\hline AVLU & Korkulu & $\begin{array}{l}\text { Malzeme } \\
\text { ve Biçim }\end{array}$ & Demir, düz biçimde & \\
\hline & Kapı & Tipi & Kesme taştan yapılı kemerli, 2-3 m aralıklı 2 kap1 & \\
\hline & & Malzeme & Tahtadan yapılı, üzeri madeni levha kaplı & \\
\hline & & Ölçü & Bir insanın geçebileceği kadar & \\
\hline & Yeşil Ala & & Değişken biçimli ve avlu çevresi veya ortasında & \\
\hline & Havuz & Biçim & Avlu ortasinda & \\
\hline & & Malzeme & Mermer veya taş & \\
\hline & & Ölçü & Değişken & \\
\hline & $\begin{array}{l}\text { Çeşme } \\
\text { Kuyu }\end{array}$ & $\begin{array}{l}\text { Biçim ve } \\
\text { Malzeme }\end{array}$ & $\begin{array}{l}\text { Avlu veya yapı duvarında, merdiven altında ve } \\
\text { Taş malzeme }\end{array}$ & \\
\hline & Revak & & Avluya bakan şekilde ve eşit ölçülerde sıralı & \\
\hline & & Biçim & $\begin{array}{l}\text { Avludan } 25-30 \mathrm{~cm} \text { yüksekte, üstü kapalı ve } \\
\text { avluya dönük }\end{array}$ & \\
\hline & Eyvan & & & \\
\hline & & Malzeme & Ahşap & \\
\hline & Yapım T & niği & Kagir & \\
\hline & Kat Yül & kliği & Genellikle 2 katlı & \\
\hline & Malzem & & $\begin{array}{l}\text { 1. kat taş kagir, 2. kat ahşap iskelet arası tuğla } \\
\text { döşeme }\end{array}$ & \\
\hline & Cephe Y & & Avluya dönük, sokağa sağır duvarlı, çıkma & \\
\hline & Çıkma & & $\begin{array}{l}\text { Taş, taş+ahşap ve dökme, demir konsollu Cephe } \\
\text { boyunca, kapalı, köşe, , gönye, açık çıkma ve } 60 \\
\text { cm ölçüsünde }\end{array}$ & \\
\hline YAPI & Kapı & & Ahşap, bazen işlemeli & \\
\hline & & D1ş Cephe & $\begin{array}{l}\text { Zeminde kare dikdörtgen, dairesel, üstte } \\
\text { dikdörtgen } 2 \text { veya } 4 \text { kanatll,1 kanat sabit }\end{array}$ & \\
\hline & Pencere & $\begin{array}{l}\text { Kuş } \\
\text { Penceresi }\end{array}$ & $\begin{array}{l}50-60 \mathrm{~cm} \text { duvar içinde yerden } 3-4 \mathrm{~m} \text { yüksekte ve } \\
\text { desenli }\end{array}$ & \\
\hline & Duvar & $\begin{array}{l}\text { Kalınlık ve } \\
\text { Malzeme }\end{array}$ & 50-100 cm kalınlıkta Taş ve ahşap & \\
\hline & Çatı ve s & aklar & Kiremit örtülü, beşik ve kırma çatı & \\
\hline & Bacalar & & Taş malzeme & $=$ \\
\hline & Malzeme & & $\begin{array}{l}\text { Taş döşemeli, 100-130 cm genişlikte kaldırıma } \\
\text { sahip }\end{array}$ & \\
\hline & Biçim ve & enişlik & $\begin{array}{l}\text { Dar ve organik, bazen çıkmaz, ortasında } 6-10 \mathrm{~cm} \\
\text { x } 60-100 \mathrm{~cm} \text { su kanalı var ve } 3-3.5 \text { m genişlikte }\end{array}$ & \\
\hline SOKAK & Duvar & & Dar ve $3 \mathrm{~m}$ yükseklikte taş ve sağır yüzeyli & \\
\hline & Merdive & Basamak & Eğimli sokaklarda iki yanda yer alacak şekilde & \\
\hline & Kabaltı & & $\begin{array}{l}180-250 \mathrm{~cm} \text { yüksekliğinde, taş veya ahşap } \\
\text { malzeme }\end{array}$ & \\
\hline & Su Olukl & & Sokağın iki yanında olacak şekilde & \\
\hline MEYDAN & Biçim & & $\begin{array}{l}\text { Çok fazla ortaya çıkamamış, kavşak olan açık } \\
\text { alanlarda }\end{array}$ & \\
\hline
\end{tabular}

Yapılan doku çalışmasında yapılarda taş ile birlikte ahşap kullanımının yoğun olduğu, sokakların ise kıvrımlı ve taş döşemeli olduğu belirlenmiştir. 


\section{Mekânsal Gelişim Haritalarının Karşılaştırılması}

Anıtsal Yapılar: Gaziantep ve Antakya içerisinde yer alan anıtsal yapılar zaman içerisinde imar planında alınan kararlar doğrultusunda değişiklik geçirmiştir. 1929 ve 1935 yılından itibaren meydana gelen bu değişiklikler Şekil 5'de görülmektedir. Yıllar içerisinde bazı yapı alanlarının küçüldüğü, işlevinin değiştirildiği belirlenmiştir.

Şekil 5. Yıllara Göre Antakya ve Gaziantep Anıtsal Yapı Dağılımı
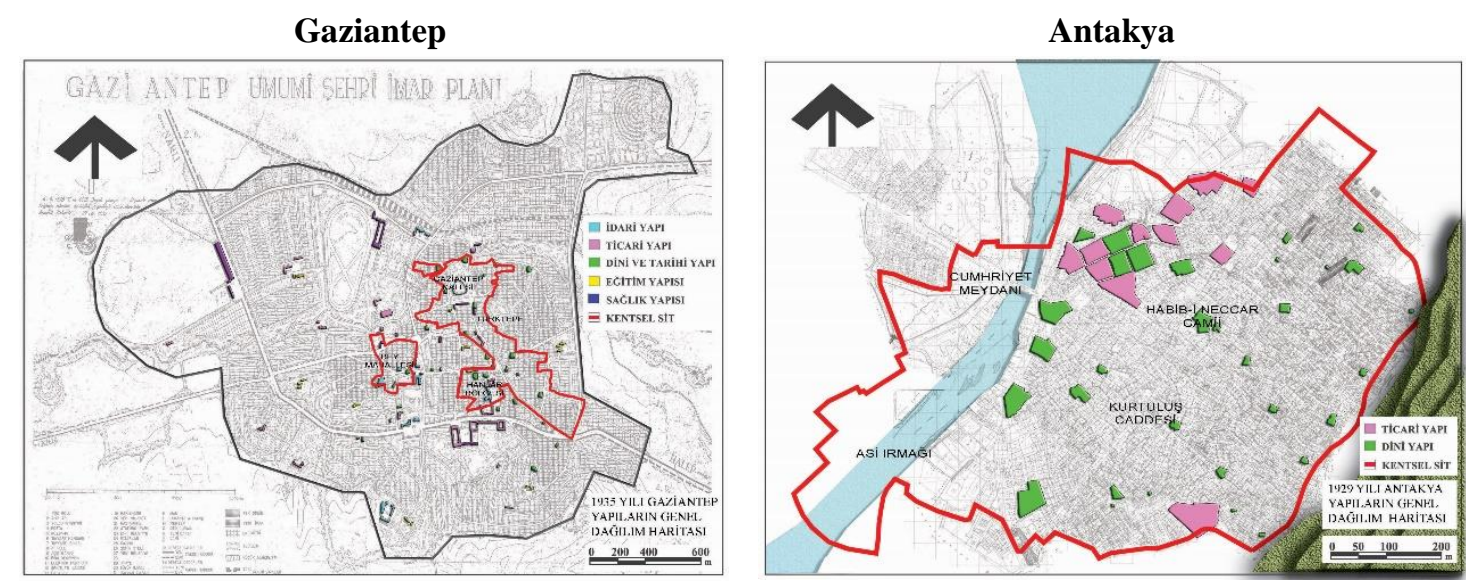

1935 Yılı

1929 Yılı

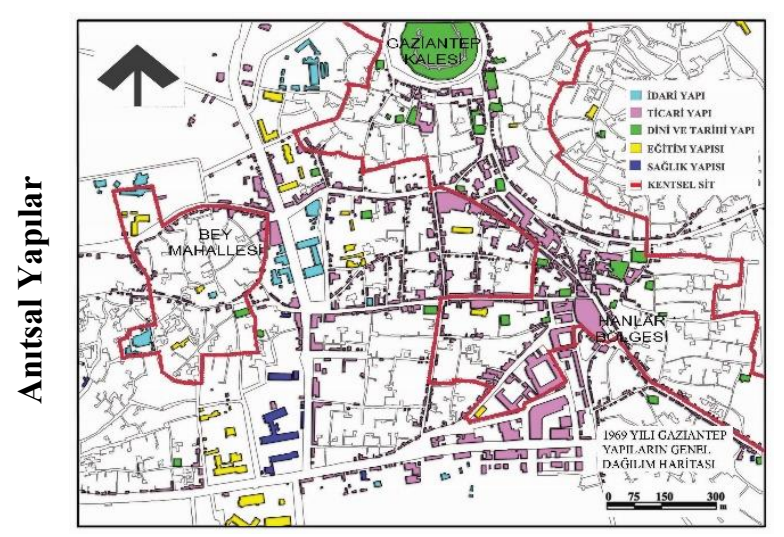

1969 Yılı

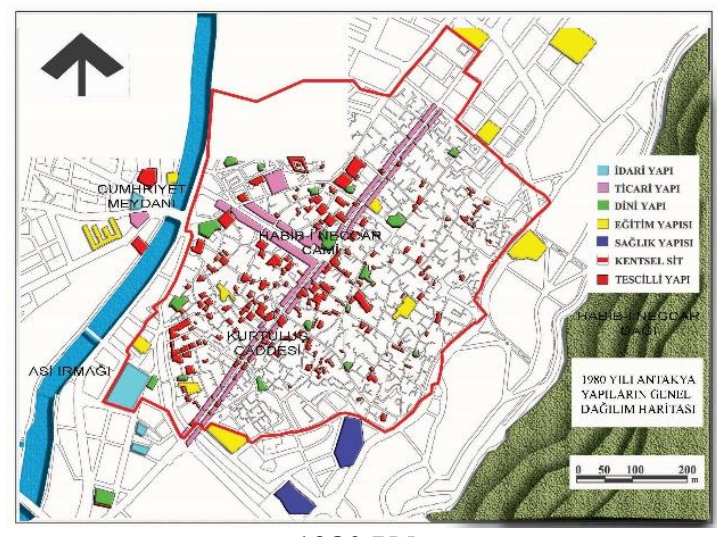

1980 Yılı

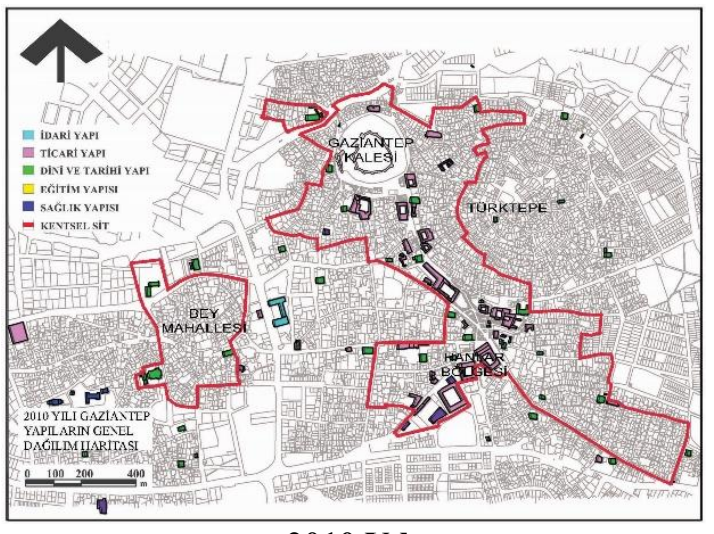

2010 Yılı

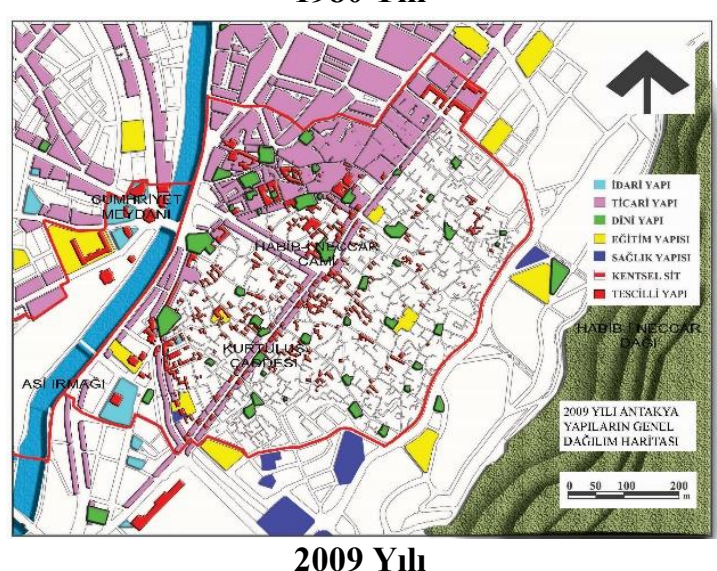

Sivil Mimarlık Örnekleri: Sivil mimarlık örneklerine ait veriler 2009 ve 2010 yılını içermektedir. Gaziantep' de 2010 yılına kadar olan süreçte yok olan yapılar Şekil 6'da, görülebilmektedir. Antakya'da ise veriler sadece 2009 yılına ait olduğu için önceki yıllarla karşılaştırması mümkün olmamıştır. 
Şekil 6. Yıllara Göre Antakya ve Gaziantep Sivil Yapı Dağılımı

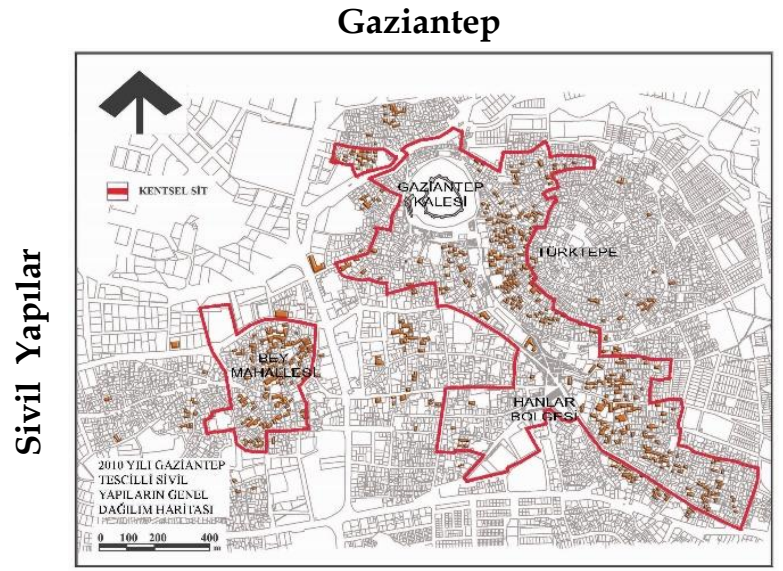

2010 Y1l1

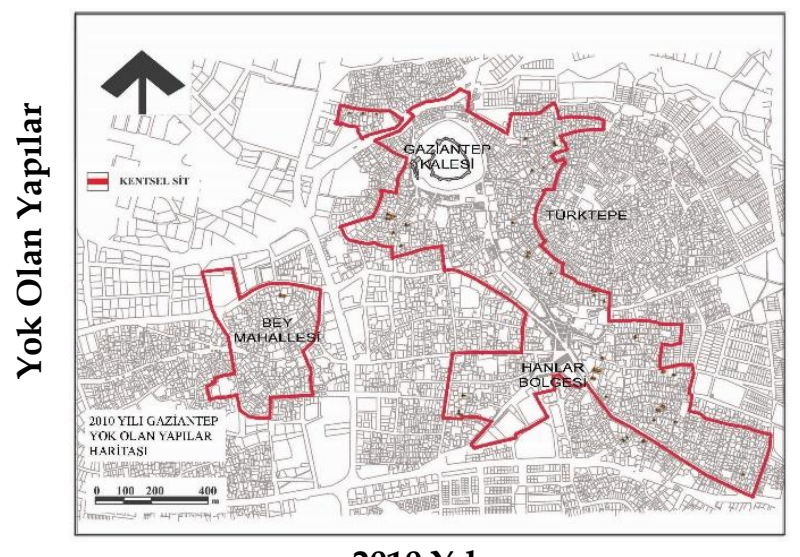

Antakya

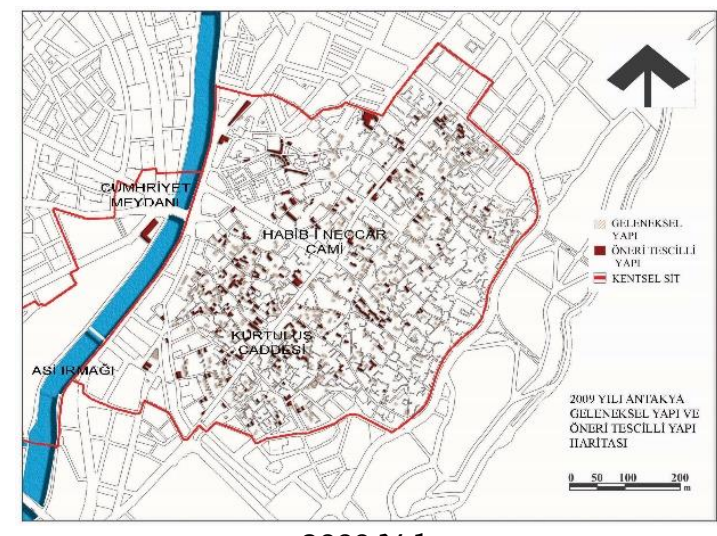

2009 Y1lı

2010 Yil1

Ulaşım Ağı: Yerasimos (1992), İslamiyet'in hâkim olduğu şehirlerde sokakları; "Belirli yapılar ve ticaret merkezlerini bağlayan, ulaşımı sağlayan ana akslar, merkezi ve mahalleleri bağlayan ikincil akslar ve mahallelerin içindeki yabancıların ulaşması istenmeyen akslar" olarak sınıflandırmıştır. Konut bölgelerinde mahremiyeti ve güvenliği sağlamak amacıyla tasarlanmıştır sokak dokusu labirenti andıran, çıkmaz sokaklarla beslenen bir yol ağı görünümündedir (Yıldırım ve Çağdaş, 2018).

Her iki kentte de cadde ve sokak dokusunda planlama kararlarıyla birtakım değişiklikler yapılmıştır. Bu değişikliklerin belirlenebilmesi amacıyla oluşturulan ulaşım ağı haritaları Şekil 7'de verilmiştir. 
Şekil 7. Yıllara Göre Antakya ve Gaziantep Ulaşım Ağ
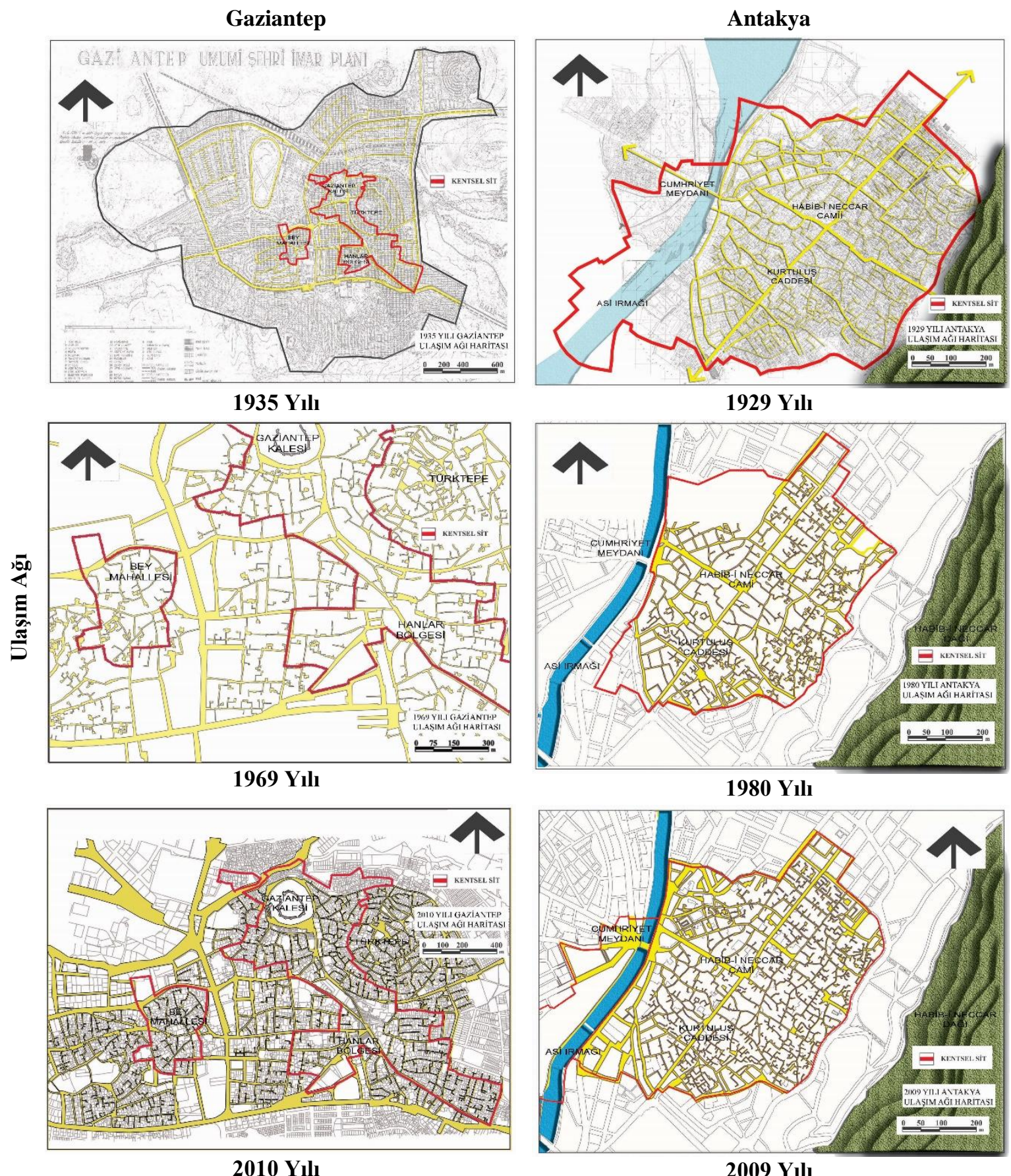

1929 Yılı

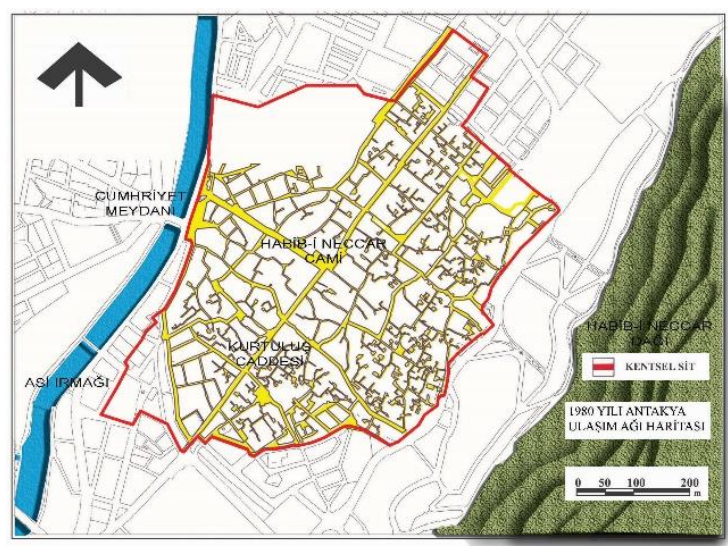

1980 Yılı

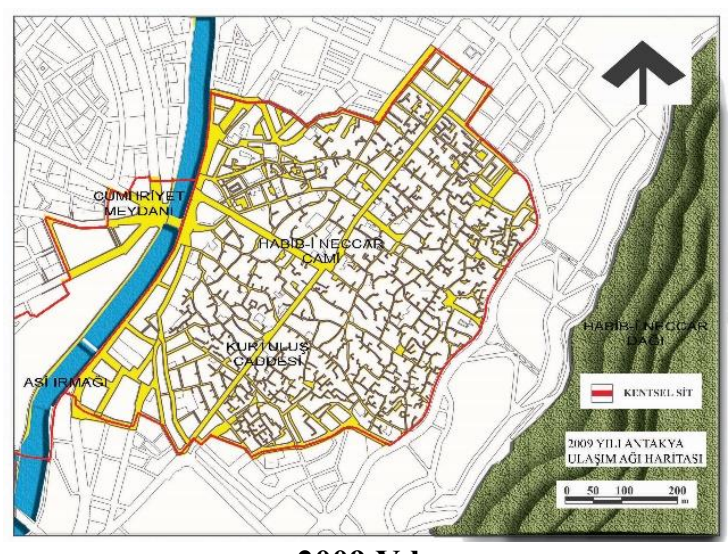

2009 Yılı

İnceleme sonunda Gaziantep için 1935 yılında hızlanan ulaşım ağı 2010 yılı itibariyle de gelişmeye devam etmiştir. Antakya'da ise yeni yolların açıldığı ve ulaşım ağının yıllar içerisinde değişikliğe uğradığı tespit edilmiştir. 
Yeşil Alan: Her iki kente ait yeşil alan dağılım haritaları Şekil 8'de görülebilmektedir

Şekil 8. Yıllara Göre Antakya ve Gaziantep Yeşil Alan Dağılımı
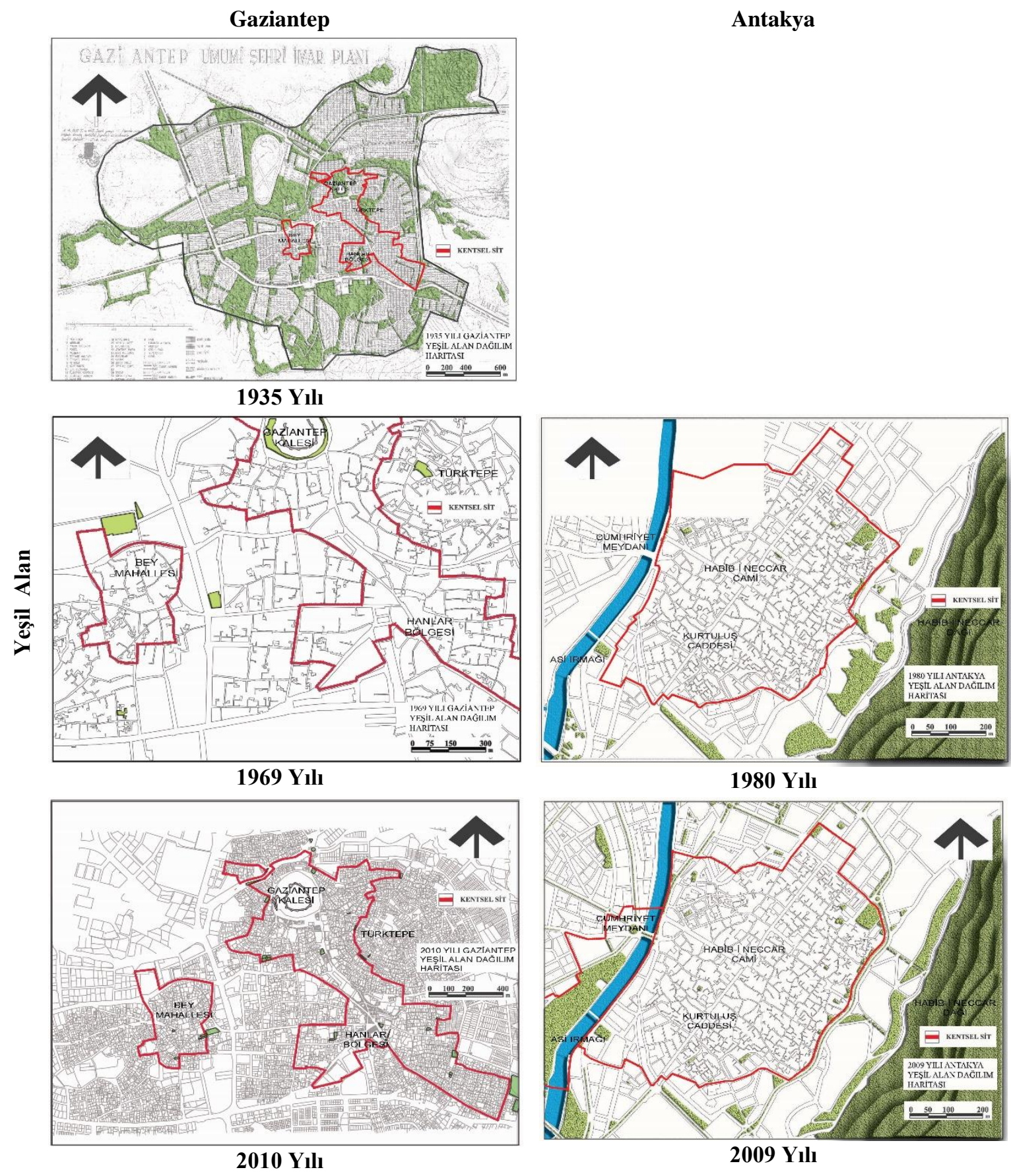

İnceleme sonunda her iki kent için de yeşil alan miktarında değişiklikler olduğunu söylemek mümkündür. Antakya Kentsel Sit Alanına ait ilk harita 1980 yılına ait olduğu için değerlendirme bu tarihten itibaren yapılmıştır. 1980 yılı sonrası bazı bölgelerde yeşil alan miktarının değişiklik gösterdiği 2009 yılı haritasında görülebilmektedir 


\section{Sonuç ve Öneriler}

Gaziantep ve Antakya kentleri yapısal olarak incelendiğinde tıpkı İslam ve Anadolu şehirlerinde olduğu gibi, yol şebekesinin ortak sosyal ve kültürel anlayış doğrultusunda toplum tarafından, belirlendiği görülmektedir (Yıldırım ve Çağdaş, 2018). Düzensiz bir şekilde olan sokaklar, mahremiyeti ve özellikle de güvenliği sağlamak için uç noktalarından kapatılarak çıkmaz haline getirilmiş; böylece başkalarının geçişine kapatılan sokak, belirli bir gruba ait özel bir yola dönüştürülmüştür. Evler doğrudan sokağa değil, sokağı sınırlayan duvar gerisindeki avluya açılarak, aile hayatı gizlenmeye çalışılmıştır. Mahalleler ise birbirinden belirgin şekilde ayrılmış olup bazen mahalleler arasına duvar çekilmiştir (Can, 1995).

Gaziantep şehri Hitit, Asur, Bizans, İslam, Selçuklu, Türk-İslam ve Osmanlı dönemlerini yaşamış̧ır. Memluk hakimiyeti ile Han, Hamam gibi yapıların inşası ile gelişmiş, son olarak da Osmanlı geleneğiyle günümüzdeki halini alan bir kent olarak değerlendirilebilir. Özellikle Memluk Dönemi ile başlatan Han, Hamam, Cami gibi yapılardaki mimari üslup bunu desteklemektedir. Osmanlı hakimiyetine giren şehir hızlı bir gelişme kaydetmiş ve ticaret kenti olarak nitelendirilmeye başlanmıştır.

Antakya ise Roma döneminde izgara plan sistemiyle oluşturulmuş, sonraki yllarda ise İslam kenti özellikleriyle birleştirilmiş bir karakter sergilemektedir. Bu birleşim değerlendirildiğinde her iki dönem için de konut yapısının değişmediği, avlulu yüksek duvarlı içe dönük yapı düzeninin korunduğu görülmektedir. Bu noktada değişim büyük ölçüde sokak yapısında olmuştur. Izgara plan sisteminde yer alan yol ağının kıvrımlı organik bir yapıya dönüştüğü görülmektedir. Anadolu'da bugün varlığını sürdüren eski yerleşme bölgelerine sahip kentlerde olduğu gibi, Antakya kenti eski kent yerleşiminin mekânsal yapısını belirleyen dönem Osmanlı Dönemi olmuştur. (Asarc1kl1,1989).

Çalışma ile yakın iki il olan Antakya ve Gaziantep karşılaştırıldığında konut düzeni ve yol dokusu olarak benzerlik taşıdığı, ancak bazı malzeme kullanımlarında farklılıklar gösterdiği belirlenmiştir. Yakın mesafede bulunan iki kent içerisinde bile farklılıklar olduğu değerlendirildiğinde, yapılacak olan çalışmalarda kentin genel karakteriyle uyumlu kararlar verilmesinin önemine vurgu yapılmıştır.

Çalışma alanı olarak belirlenen Antakya ve Gaziantep Kentsel Sit Alanı ile ilgili geçmişe dönük bazı verilere ulaşılamaması çalışma açısından sınırlık oluşturmuş̧ur. Sivil mimarlık örneklerine ait veriler yalnızca 2009 ve 2010 yılını içermektedir. Gaziantep' de 2010 yılına kadar olan süreçte yok olan yapılar görülebilmektedir. Antakya'da ise geçmişe dair veriler elde edilmediği için veri haritası oluşturulamamıştır.

Elde edilen veriler 1şı̆̆ında her iki kentte de cadde ve sokak dokusunda planlama kararlarıyla birtakım değişiklikler yapıldığı tespit edilmiştir. Yıllar içerisinde anıtsal ve sivil yapılarda eklentiler yapıldı ̆̆ı, işlevinin değiştirildiği veya yok olduğu belirlenmiştir. Oysaki Rodwell (2014), Yuen (2005, Radoslav vd. (2013), Wang (2011) tarihi çevre içerisinde yapılan koruma çalışmalarının bir bütünlük arz etmesi ve sürdürülebilir uygulamalar içermesi gerektiğini savunmaktadır. Kentsel bir tarihi dokunun korunması cadde, sokak, avlu, meydan, açık ve yeşil alanlar gibi yerleşim ölçeğindeki öğeleri ve kentsel donatı ölçeğindeki öğeleri korumakla mümkündür. Hemen hemen tüm yerleşmelerinde kültürel birikimin zengin olduğu ülkelerde, yarının kentlerini biçimleyecek planlama çalışmalarının önemi büyüktür. Bu durumun söz konusu olduğu ülkelerde tek başına ne bir mimar, ne de bir şehir plancısının uzmanlı̆̆ının yeterli olmayacağı açıktır. Bu nedenle meslek disiplinleri arasında bir görüş alışverişi ve bütünlük arz eden bir çalışma anlayışı gerekmektedir (Ekinci, 1992).

\section{Teşekkür}

Bu çalı̧̧ma, Çukurova Üniversitesi, Fen Bilimleri Enstitüsü, Peyzaj Mimarlığı Anabilim Dalı'nda tamamlanan "Kent Kimliği Açısından Tarihi Çevre Koruma ve Yenileme Çalışmalarının Değerlendirilmesinde Bir Model Önerisi” adlı doktora çalışmasından üretilmiştir. Çalışma, Çukurova Üniversitesi, Bilimsel Araştırma Projeleri Koordinasyon Birimi tarafindan 2016-7583 nolu proje ile desteklenmiş olup, bu desteklerinden dolayı teşekkür ederiz.

\section{Kaynaklar}

1. Akbay, V.A. (2006). Antakya Örneğinde Tarihi Ev Bahçeleri. Mustafa Kemal Üniversitesi Fen Bilimleri Enstitüsü Yüksek Lisans Tezi, Hatay, 76 s. 
2. Arıman, B. (2002). Antakya Kenti Tarihi Doku İçinde Tipolojik Analiz Çalışmaları. İstanbul Teknik Üniversitesi Fen Bilimleri Enstitüsü Yüksek Lisans Tezi, İstanbul, $128 \mathrm{~s}$.

3. Arslan, R. (1993). Kent Planlamasında Değerlendirme Teknikleri. Yıldız Teknik Üniversitesi Mimarlık Fakültesi, Şehir ve Bölge Planlama Bölümü. Üniversite Yayın No:270, Fakülte Yayın No: MF-SBP 93.020, İstanbul.

4. Asarcıklı, M. (1989). Antakya Kent Formunu Oluşturan Öğelerin Araştırılıp Değerlendirilmesi. Gazi Üniversitesi Fen Bilimleri Enstitüsü Yüksek Lisans Tezi. Ankara, $171 \mathrm{~s}$.

5. Başel, E. (2004). Gaziantep Tarihi Kent Dokusu İçinde Yer Alan Meydan, Sokak, Avlu ve Yap1 Bölümlerinin Detay ve Materyal Yönünden İrdelenmesi. Çukurova Üniversitesi Fen Bilimleri Enstitüsü Yüksek Lisans Tezi, Adana, 164 s.

6. Başgelen, N. (1999). Dünya Kültür Mirasında Gaziantep. Arkeoloji ve Sanat Yayınları (Kentbank Dünya Kültür Mirasında Kentlerimiz ), İstanbul.

7. Can, Y. (1995). İslam Şehirlerinin Fiziki Yapısı. Türk Diyanet Vakfi Yayınları/169. İlmi Eserler Serisi:39, Ankara.

8. Cohen, N. (1999). Urban Conservation. The Mit Press, 359 s, Cambridge.

9. Çam, N. (2006). Türk Kültür Varlıkları Envanteri Gaziantep 27. Atatürk Kültür, Dil ve Tarih Yüksek Kurumu Türk Tarih Kurumu Yayınları XXVVII. Dizi-Sayı 10, Ankara.

10. Çetin, M. (2001). Tarihsel Açıdan Gaziantep'in Kentsel Gelişimi. Çukurova Üniversitesi Yüksek Lisans Tezi (yayınlanmamış) Adana,

11. Demir, A. (1996). Çağlar İçinde Antakya. Akbank Yayınları, İstanbul.

12. Dik, G. (2006). Kültür Varlığı Sivil Mimarlık Ürünlerinde İşlev Değişiklikleri Sonucu Ortaya Çıkan Sorunlar: Gaziantep Merkezi Örneği. Çukurova Üniversitesi Fen Bilimleri Enstitüsü Yüksek Lisans Tezi, Adana, $205 \mathrm{~s}$.

13. Ekinci, O. (1992). Kent Planlamasında Kültürel Kimlik Sorunu. Ege Mimarlık Dergisi.(2): 39-42.

14. Erdoğan, E. (1996). Anadolu Avlularının Özellik Ve Düzenleme İlkeleri Üzerinde Karşılaştırmalı Bir Araştırma. Ankara Üniversitesi Fen Bilimleri Enstitüsü Doktora Tezi, Ankara, 567 s.

15. Esendemir, Ş. (2015). Şehrin Kökeni, Muhafazakar ve Modernist Halleri. Şehir ve Medeniyet. (9):32-37.

16. Evliya Çelebi Seyahatnamesi (1982). (Haz: İsmet Parmaksızoğlu). Kültür ve Turizm Bakanlığı Yayınları: 506. 1000 Temel Eser Dizisi:88. Ankara.

17. Eyüpgiller, K. K. (2013). Korumanın Türkiye’ye Özgü Sorunları ‘'̇hmal Edilmiş ve Sağlıksız Kentsel Sitlerde Koruma'. Yap1 Dergisi, (380): 88-91.

18. Gökhan, İ. (2010). Memlukler Döneminde Antakya(1268-1516).(A Gündüz ve S Kaya Editör).Hatay Araştırmaları-I, Cantekin Matbaası, Ankara, s 1-26.

19. Gündüz, A. (2009). XVI. Yüzyılda Antakya Kazası (1550-1584).Mustafa Kemal Üniversitesi Yayınları No:23, Hatay.

20. Gündüz, A., Gülcü, A. (2009). XVI. Yüzyılda Antakya Nahiyesi (1526-1584). Mustafa Kemal Üniversitesi Sosyal Bilimler Enstitüsü Dergisi,6 (12):289-323.

21. Güzelbey, C.C. (1966). Gaziantep Şer’i Mahkeme Sicilleri. Gaziantep Kültür Derneği, Cilt:142-143, Sayı:46, Gaziantep.

22. Güzer, B. (2007). Antakya ve Boston Kentleri Üzerinde Açık Alan Tipolojilerinin Dönüşümünün irdelenmesi. Ankara Üniversitesi Fen Bilimleri Enstitüsü Yüksek Lisans Tezi, Ankara, 100 s.

23. Kıratlı, M. (2013). Gaziantep İli Şahinbey İlçesi, 18 Pafta, 99 Ada, 2 Parselde Yer Alan Sivil Mimarlık Yapıs1 Restorasyon Projesi. İstanbul Teknik Üniversitesi Fen Bilimleri Enstitüsü Yüksek Lisans Tezi, İstanbul, $218 \mathrm{~s}$.

24. Kocaoğlu, S.E. (2016). Antakya Tarihi Kent Dokusunun Kentsel Tasarım Açısından İncelenmesi ve Bir Örnek Çalışma. Bartın Üniversitesi Fen Bilimleri Enstitüsü Yüksek Lisans Tezi, Bartın, 212 s.

25. Kuban, D. (2001). Türkiye'de Kentsel Koruma Kent Tarihleri ve Koruma Yöntemleri. Tarih Vakfı Yurt Yayınları, İstanbul.

26. Radoslav, R., Branea, A.M., Gaman, S.M. (2013). Rehabilitation Through a Holistic Revitalization Strategy of Historical City Centres Timisoara, Romania. Journal of Cultural Haritage (Elsevier) $14 \mathrm{~S}(2013) \mathrm{e} 1-\mathrm{e} 6$

27. Rifaioğlu, M.N. (2003). Antakya Eski Kent Dokusunda Gazipaşa Sokağının Mekânsal Analizi. Çukurova Üniversitesi Fen Bilimleri Enstitüsü Yüksek Lisans Tezi, Adana, $201 \mathrm{~s}$.

28. Rifaioğlu, M.N. (2015). Mekânsal-Kültürel Değerleri ve Koruma Sorunsalı", Mimarlık Dergisi, TMMOB Mimarlar Odası Ankara Şubesi Yayınları, 381: 53-58.

29. Ömeroğlu, C. (2006). Antakya Kentinin Özgünlüğü Ve Günümüz Koruma Sorunlarının Antakya Kentsel Sit Alanında İrdelenmesi. Gazi Üniversitesi Fen Bilimleri Enstitüsü Yüksek Lisans Tezi, Ankara, 215 s.

30. Özalp, D. (2008). Tarihî Kent İmajının Korunmasında Kentsel Tasarım Antakya Örneği. Kültür ve Turizm Bakanlığı Kültür Varlıkları ve Müzeler Genel Müdürlüğü Uzmanlık Tezi, Ankara, 179 s.

31. Özdeğer, H. (1996).Gaziantep. Türk Diyanet Vakfi İslâm Ansiklopedisi 13:466-475, İstanbul. 
32. Rodwell, D. (2014). Sustannability and the Holistic Approach to the Conservation of Historic Cities. Journal Of Architecture Conservation, 9:1, 58-73.

33. Sahillioğlu, H. (1991). Antakya. Türk Diyanet Vakfı İslam Ansiklopedisi 3:228-232, İstanbul.

34. Sbeinati, M.R., Darawcheh , R., Mouty, M. (2005). The Historical Earthquakes of Syria: An Analysis of Large and Moderate Earthquakes from 1365 B.C. to 1900 A.D. Annals of Geophysics 48(3): 347-435.

35. Tatlıgil, F. (2005). Gaziantep Kentinin Geleneksel Konut Dokusunun Ve Sosyo-Kültürel Yapısındaki Değişimin İncelenmesi. Yıldız Teknik Üniversitesi Fen Bilimleri Enstitüsü Yüksek Lisans Tezi, İstanbul, $131 \mathrm{~s}$.

36. Tekin, M. (2000). Hatay Tarihi. Atatürk Kültür Merkezi Başkanlığı Yayınları, Ankara.

37. Tozlu, S. (2009). Antakya Tarihi Bibliyografyası. Fırat Üniversitesi Orta Doğu Araştırmaları Merkezi Yayınları No:17 Tarih Şubesi Yayınları No:14, Elazığ.

38. Tuncel, M. (1996). Bugünkü Gaziantep. Türk Diyanet Vakfi İslam Ansiklopedisi, 13: 474-475.

39. Turan, O. (1971). Selçuklular Zamanında Türkiye. Ötüken Yayınları, Yayın no:573, Kültür Serisi:255, İstanbul.

40. Ŭgur, H. (2004). Geleneksel Şehirsel Mekanlar, Değerlendirme ve Korunmaları Bağlamında Sistematik Yaklaşım: Gaziantep Örneği. İstanbul Teknik Üniversitesi Fen Bilimleri Enstitüsü Doktora Tezi, İstanbul, $133 \mathrm{~s}$.

41. Ünal, Z.G. (2001). Bilgisayar Destekli Tarihi Çevre Koruma Bilgi Sistemi Oluşturulması ve Gaziantep Kentsel Sit Alanında Örneklenmesi. Yıldız Teknik Üniversitesi Fen Bilimleri Enstitüsü Doktora Tezi, İstanbul, $312 \mathrm{~s}$.

42. Wang, J. (2011). Problems and Solutions İn The Protection of Historical Urban Areas. Frontiers of Architectural Research(Elsevier).1:40-43

43. Yerasimos, S., Tekeli, İ., Yerolimpos, A., Lory, B., Popovic, A., Laurent, B.A., Georgeon, F., Minassian, A.T., Dumont, P., Ilbert, R., Moulim, A.M. (1996). Modernleşme Sürecinde Osmanlı Kentleri .(Dumont P and Georgeon F Editör). Tarih Vakfı Yurt Yayınları, İstanbul.

44. Yıldırım, G.E., Çağdaş, G. (2018). Gaziantep Geleneksel Mimari Dokusunun Sosyo-Kültürel Bağlamda Mekan Dizimsel Analizi. Gaziantep Üniversitesi Sosyal Bilimler Dergisi,17:2, 508-532.

45. Yoldaş, H. (2014). Sürdürülebilirlik Bağlamında Sosyo-Kültürel Etkenler Açısından Antakya Konutlarının Mekânsal Analizi. İstanbul Kültür Üniversitesi Fen Bilimleri Enstitüsü Yüksek Lisans Tezi, İstanbul, $182 \mathrm{~s}$.

46. Yuen, B. (2005). Searching For Places İdentity in Singapore.Habitat İnternational, 29(2), 197-214.

47. Yüce, B. (2010). Osmanlı Son Dönemi ile Erken Cumhuriyet Dönemi Arasında Gaziantep’te Mimari Dokunun Değişimi (1839-1950). İstanbul Teknik Üniversitesi Fen Bilimleri Enstitüsü Yüksek Lisans Tezi, İstanbul,178 s. 